\title{
Contribution and pathways of diazotroph-derived nitrogen to zooplankton during the VAHINE mesocosm experiment in the oligotrophic New Caledonia lagoon
}

\author{
Brian P. V. Hunt ${ }^{1,2}$, Sophie Bonnet ${ }^{3,4}$, Hugo Berthelot ${ }^{3}$, Brandon J. Conroy ${ }^{5}$, Rachel A. Foster ${ }^{6}$, and Marc Pagano Ma $^{3,4}$ \\ ${ }^{1}$ University of British Columbia, Department of Earth, Ocean and Atmospheric Sciences, Vancouver, V6T 1 Z4, \\ British Columbia, Canada \\ ${ }^{2}$ Hakai Institute, P.O. Box 309, Heriot Bay, BC, V0P 1H0, Canada \\ ${ }^{3}$ Aix Marseille Université, CNRS/INSU, Université de Toulon, IRD, Mediterranean Institute of Oceanography (MIO) \\ UM110, 13288, Marseille, France \\ ${ }^{4}$ IRD/CNRS/Aix-Marseille University, Mediterranean Institute of Oceanography (MIO), IRD Noumea, 101 Promenade R. \\ Laroque, BPA5, 98848, Noumea CEDEX, New Caledonia (France) \\ ${ }^{5}$ Department of Biological Sciences, Virginia Institute of Marine Science, College of William and Mary, Gloucester Point, \\ Virginia 23062, USA \\ ${ }^{6}$ Department of Ecology, Environment, and Plant Sciences, Stockholm University, 10691 Stockholm, Sweden
}

Correspondence to: Brian P. V. Hunt (bhunt@eos.ubc.ca)

Received: 28 November 2015 - Published in Biogeosciences Discuss.: 18 January 2016

Revised: 30 April 2016 - Accepted: 3 May 2016 - Published: 31 May 2016

\begin{abstract}
In oligotrophic tropical and subtropical oceans, where strong stratification can limit the replenishment of surface nitrate, dinitrogen $\left(\mathrm{N}_{2}\right)$ fixation by diazotrophs can represent a significant source of nitrogen $(\mathrm{N})$ for primary production. The VAHINE (VAriability of vertical and tropHIc transfer of fixed $\mathrm{N}_{2}$ in the south-wEst Pacific) experiment was designed to examine the fate of diazotroph-derived nitrogen (DDN) in such ecosystems. In austral summer 2013, three large $\left(\sim 50 \mathrm{~m}^{3}\right)$ in situ mesocosms were deployed for 23 days in the New Caledonia lagoon, an ecosystem that typifies the low-nutrient, low-chlorophyll environment, to stimulate diazotroph production. The zooplankton component of the study aimed to measure the incorporation of DDN into zooplankton biomass, and assess the role of direct diazotroph grazing by zooplankton as a DDN uptake pathway. Inside the mesocosms, the diatom-diazotroph association (DDA) het-1 predominated during days 5-15 while the unicellular diazotrophic cyanobacteria UCYN-C predominated during days 15-23. A Trichodesmium bloom was observed in the lagoon (outside the mesocosms) towards the end of the experiment. The zooplankton community was dominated by copepods ( $63 \%$ of total abundance) for the duration of the
\end{abstract}

experiment. Using two-source $\mathrm{N}$ isotope mixing models we estimated a mean $\sim 28 \%$ contribution of DDN to zooplankton nitrogen biomass at the start of the experiment, indicating that the natural summer peak of $\mathrm{N}_{2}$ fixation in the lagoon was already contributing significantly to the zooplankton. Stimulation of $\mathrm{N}_{2}$ fixation in the mesocosms corresponded with a generally low-level enhancement of DDN contribution to zooplankton nitrogen biomass, but with a peak of $\sim 73 \%$ in mesocosm 1 following the UCYN-C bloom. qPCR analysis targeting four of the common diazotroph groups present in the mesocosms (Trichodesmium, het-1, het-2, UCYN-C) demonstrated that all four were ingested by copepod grazers, and that their abundance in copepod stomachs generally corresponded with their in situ abundance. ${ }^{15} \mathrm{~N}_{2}$ labelled grazing experiments therefore provided evidence for direct ingestion and assimilation of UCYN-C-derived $\mathrm{N}$ by the zooplankton, but not for het-1 and Trichodesmium, supporting an important role of secondary pathways of DDN to the zooplankton for the latter groups, i.e. DDN contributions to the dissolved $\mathrm{N}$ pool and uptake by nondiazotrophs. This study appears to provide the first evidence of direct UCYN-C grazing by zooplankton, and indicates that UCYN-C-derived $\mathrm{N}$ contributes 
significantly to the zooplankton food web in the New Caledonia lagoon through a combination of direct grazing and secondary pathways.

\section{Introduction}

Dinitrogen $\left(\mathrm{N}_{2}\right)$ fixation by diazotrophs is considered to be the most important external source of reduced nitrogen $(\mathrm{N})$ for the ocean, exceeding atmospheric and riverine inputs (Gruber et al., 2004). The nitrogenase enzyme gives diazotrophs the capacity to reduce $\mathrm{N}_{2}$ gas into bioavailable ammonium. In the oligotrophic tropical and subtropical oceans, where strong stratification limits the upward mixing of nitrate replete deep water into the photic zone, this new $\mathrm{N}$ is particularly important, sustaining $\sim 50 \%$ of primary productivity (Karl et al., 1997). In addition, some experimental research indicates that $\mathrm{N}_{2}$ fixation will be enhanced by rising atmospheric carbon dioxide $\left(\mathrm{CO}_{2}\right)$ concentrations and ocean warming, highlighting a potentially increasingly important role of diazotrophs in the oceanic carbon and $\mathrm{N}$ cycles (Hutchins et al., 2007, 2009; Levitan et al., 2007; Sheridan and Landry, 2004).

Stable isotope analysis has served as a powerful tool for investigating the contribution of new $\mathrm{N}$ to pelagic food webs (Carpenter et al., 1999; Hannides et al., 2009; Landrum et al., 2011; Mompean et al., 2013; Montoya et al., 2002). $\mathrm{N}_{2}$ gas has an $\mathrm{N}$ isotope ratio $\left(\delta^{15} \mathrm{~N}\right)$ of $0 \%$ and preferential uptake of ${ }^{14} \mathrm{~N}$ leads to $\delta^{15} \mathrm{~N}$ values as low as $-2.5 \%$ ofor diazotrophs (Montoya et al., 2002). By comparison, the average ocean nitrate $\delta^{15} \mathrm{~N}$ value is $\sim 5 \%$ o (Sigman et al., 1997, 1999), leading to higher $\delta^{15} \mathrm{~N}$ values for primary producers using nitrate as their nitrogen source. The $\delta^{15} \mathrm{~N}$ values of zooplankton reflect the balance between these contrasting $\mathrm{N}$ sources, the relative contributions of which can be estimated using a two-part mixing model (Montoya et al., 2002). This modelling approach has been used to demonstrate a significant contribution of diazotroph-derived N (DDN) to particulate matter and zooplankton biomass (Aberle et al., 2010; Landrum et al., 2011; Loick-Wilde et al., 2012; Mompean et al., 2013; Montoya et al., 2002; Sommer et al., 2006; Wannicke et al., 2013), and transfer of DDN beyond zooplankton to micronekton (Hunt et al., 2015). However, despite this measured contribution of DDN, the predominant pathways of DDN into marine food webs are still in question (Wannicke et al., 2013).

Cyanobacteria are considered the major $\mathrm{N}_{2}$-fixing microorganisms in the ocean (Zehr, 2011). The open ocean diazotrophic cyanobacteria can be divided into three groups (Luo et al., 2012): (1) nonheterocystous filamentous cyanobacteria, e.g. Trichodesmium spp. (Capone et al., 2005); (2) heterocystous cyanobacteria frequently found in association with diatoms (diatom-diazotroph associations; DDAs; see review by Foster and O'Mullan, 2008), e.g.
Richelia in association with Rhizosolenia and Hemiaulus (Rhizosolenia and Hemiaulus are often referred to and quantified by the Richelia strain that associates with each, het1 and het-2, respectively); and (3) unicellular cyanobacterial lineages (UCYN-A, B, and C), with a size range of between 1 and $6 \mu \mathrm{m}$ (Moisander et al., 2010). Until recently research related to the role of fixed $\mathrm{N}$ in marine food webs has largely focussed on Trichodesmium spp. It is generally considered that the majority of Trichodesmium DDN reaches the food web through the release of dissolved N (Capone et al., 1994; Glibert and Bronk, 1994; Mulholland and Bronk, 2001, 2004) which is taken up by heterotrophic and autotrophic microbes (Bonnet et al., 2016a), and which are subsequently consumed by the zooplankton (Capone et al., 1997; O'Neil and Roman, 1992). Dissolved N is released through a combination of endogenous and exogenous processes, including viral lysis (Hewson et al., 2004), zooplankton sloppy feeding (O’Neil et al., 1996), or programmed cell death (Berman-Frank et al., 2004). Recent research has demonstrated that UCYN can release similar amounts of dissolved N to Trichodesmium (Berthelot et al., 2015a).

The direct pathway of DDN to pelagic food webs, via zooplankton grazing, has been considered limited due to cyanobacteria possessing cyanotoxins (Guo and Tester, 1994), large cell size in the case of filamentous cyanobacteria such as Trichodesmium spp. and Nodularia spp., and poor nutritional quality (O'Neil and Roman, 1992; O'Neil, 1999). Experimental studies of direct zooplankton grazing on cyanobacteria have yielded conflicting results. Reduced feeding and egg production rates was measured for the Baltic Sea calanoid copepods Eurytemora affinis and Acartia bifilosa when fed a mixed cyanobacteria diet (Sellner et al., 1996), while others reported that A. bifilosa feeding and egg production rates were unaffected by a diet of Nodularia spp. (Koski et al., 2002). In another Baltic Sea study, direct grazing of cyanobacteria was demonstrated to be more prevalent amongst Cladocera (small crustacean) than copepods, and that they favoured the cyanobacterium Aphanizomenon over Nodularia (Wannicke et al., 2013). Direct grazing on Trichodesmium spp. has been demonstrated for the harpacticoid copepods Macrosetella gracilis, Miracia efferata, and Oculosetella gracilis in the Caribbean (O'Neil et al., 1996; O'Neil and Roman, 1994) and Acartia tonsa in the North Atlantic (Guo and Tester, 1994). In the North Atlantic, stable isotope measured zooplankton DDN uptake suggested enhanced uptake when DDA abundance was higher than Trichodesmium spp., though the actual DDN uptake pathways could not be determined (Montoya et al., 2002). Combined, the results of previous research indicate that direct grazing can be an important pathway of DDN into marine food webs, but that it is dependent on both the cyanobacteria and zooplankton community composition.

The New Caledonian coral lagoon in the south-western Pacific is a tropical low-nutrient, low-chlorophyll (LNLC) system. Oligotrophic ocean water enters the lagoon from 
the south and is driven north by the trade winds and tidal forcing before exiting through several deep inlets in the intertidal barrier reef that forms the western boundary of the lagoon (Ouillon et al., 2010). Primary productivity is $\mathrm{N}$ limited throughout the year (Torréton et al., 2010), giving $\mathrm{N}_{2}$-fixing microorganisms a competitive advantage over nondiazotrophic organisms. High abundance of diazotrophs have been reported during the austral summer, for both Trichodesmium spp. (Rodier and Le Borgne, 2010) and UCYN (Biegala and Raimbault, 2008). The New Caledonian lagoon therefore represents an ideal location to investigate the ecosystem role of diazotrophs. Accordingly, this location was selected for the implementation of the 23-day VAHINE (VAriability of vertical and tropHIc transfer of fixed $\mathrm{N}_{2}$ in the south-wEst Pacific) mesocosm experiment in the austral summer of 2013. A full description of this experiment is provided by Bonnet et al. (2015), with core details outlined in the methods below. VAHINE was designed specifically to investigate the fate of DDN in the ecosystem, i.e. its transfer to the planktonic food web and its contribution to export production (Bonnet et al., 2016b). Here, we present the zooplankton component of the VAHINE program. Our aims were (1) to measure the contribution of DDN to zooplankton biomass, and (2) investigate the role of direct grazing by zooplankton on diazotrophs as a pathway for DDN into the zooplankton food web.

\section{Material and methods}

\subsection{Mesocosms' description}

Briefly, during VAHINE, three large-volume $\left(\sim 50 \mathrm{~m}^{3}\right)$ mesocosms (M1-3) were deployed $28 \mathrm{~km}$ off the coast $\left(22^{\circ} 9.10 \mathrm{~S}, 166^{\circ} 26.90 \mathrm{E}\right)$ in the south-west (Noumea) of the New Caledonian lagoon, from 13 January (day 1) to 4 February 2013 (day 23). The site was located at a depth of $25 \mathrm{~m}$, in close proximity to Boulari passage and thus strongly influenced by oceanic oligotrophic waters coming from outside the lagoon. Each mesocosm enclosure comprised a cylindrical bag $2.3 \mathrm{~m}$ in diameter and $15 \mathrm{~m}$ deep. The mesocosms open tops were maintained at a height of $\sim 1 \mathrm{~m}$ above the surface to prevent external water additions. Screw-top plastic bottles $(250 \mathrm{~mL})$ were attached to the bottom of the mesocosms to collect sinking particles, and these were serviced daily by scuba divers. To alleviate potential phosphorus limitation and intentionally stimulate diazotrophy, the mesocosms were fertilized with $\sim 0.8 \mu \mathrm{mol} \mathrm{\textrm {L } ^ { - 1 }}$ of dissolved inorganic phosphorus (DIP) on day 4 of the experiment. Physical conditions (Bonnet et al., 2016c), primary production, and $\mathrm{N}_{2}$ fixation rates (Berthelot et al., 2015b) were monitored daily in the mesocosms and in an adjacent control site throughout the experiment (hereafter called lagoon waters), the methods and results of which are described in detail in the cited publications.

\subsection{Zooplankton sampling and processing}

Zooplankton were sampled on seven occasions from the three mesocosms and lagoon waters (the control site), at intervals of every 3-4 days, always between 09:30 and $10: 30 \mathrm{GMT}+11$. Sampling was done with a $30 \mathrm{~cm}$ diameter, $100 \mathrm{~cm}$ long, $80 \mu \mathrm{m}$ mesh net fitted with a filtering cod end. On each sampling occasion, three vertical hauls (hereafter called Samples 1, 2, and 3) were collected from the upper $10 \mathrm{~m}$ of each site. The total volume sampled on each occasion (sum of the three nets) was $2.13 \mathrm{~m}^{3}$, representing $4 \%$ of the total mesocosm volume. As reported below, zooplankton densities did not vary appreciably over the course of the experiment, indicating that the sampling did not significantly impact the mesocosm communities.

All zooplankton samples were stored in a cooler and returned to the Amédée Island field station located 1 nautical mile from the mesocosms site for processing within 3060 min of the final net haul. Zooplankton Sample 1 was split in half, and one half was preserved in $4 \%$ buffered formaldehyde for community composition analysis and the other half was filtered onto a pre-combusted $25 \mathrm{~mm} \mathrm{GF/F}$ filter for measurement of total zooplankton biomass. Sample 2 was filtered onto a pre-combusted $\left(450^{\circ} \mathrm{C}, 4 \mathrm{~h}\right) 25 \mathrm{~mm} \mathrm{GF} / \mathrm{F}$ filter for stable isotope analysis. Sample 3 was drained using a $64 \mu \mathrm{m}$ sieve within 60-90 min of collection, and held in its original collection jar in an insulated cool container with ice packs until returning to the Noumea laboratory for processing $\sim 6 \mathrm{~h}$ later. In the Noumea laboratory, Sample 3 was filtered onto a $2 \mu \mathrm{m}$ polycarbonate filter and then frozen in a Cryovial at $-80{ }^{\circ} \mathrm{C}$ for molecular analysis of zooplankton gut contents.

Taxonomic analysis of the zooplankton community was completed using a stereo microscope, from a $1 / 8$ to $1 / 16$ fraction of each sample. Specimens were identified to the level of order and enumerated. An average of 960 individuals were counted per sample and we estimated an enumeration error of $6.4 \%$ (Gifford and Caron, 2000). The category copepod nauplii comprised a mix of calanoid, cyclopoid, and poecilostomatoid copepods. No flowmeter was used with the nets and counts were converted to individuals $\mathrm{m}^{-3}$ assuming that the net was sampled with $100 \%$ efficiency. Samples for biomass estimation were rinsed with ammonium formate to remove salt, dried at $50{ }^{\circ} \mathrm{C}$ for $48 \mathrm{~h}$, and weighed to the nearest $0.01 \mathrm{mg}$ using a microbalance. Values were converted to mg dry weight (DW) $\mathrm{m}^{-3}$.

Zooplankton samples for stable isotope analysis were first dried at $50{ }^{\circ} \mathrm{C}$ for $48 \mathrm{~h}$. Zooplankton were subsequently removed from the GF/F filter, homogenized using a mortar and pestle, and packaged into $\sim 1 \mathrm{mg}$ subsamples. Stable isotope analysis of these samples was performed at the IsoEnvironmental Laboratory, Rhodes University, South Africa, with a Europa Scientific 20-20 isotope ratio mass spectrometer (IRMS) linked to a preparation unit (ANCA SL). Casein and a mixture of beet sugar and ammonium sulfate were used as internal standards and were calibrated against the Interna- 
tional Atomic Energy Agency (IAEA) standards CH-6 and $\mathrm{N}-1$ and the IRMS certified reference material EMA-P2 (see Certificate BN/132357). $\delta^{13} \mathrm{C}$ and $\delta^{15} \mathrm{~N}$ values were determined in parts per thousand (\%o) relative to external standards of Vienna Pee Dee Belemnite and atmospheric N. Repeated measurements of an internal standard indicated measurement precision of \pm 0.09 and $\pm 0.19 \%$ for $\delta^{13} \mathrm{C}$ and $\delta^{15} \mathrm{~N}$ values, respectively.

Samples of suspended particulate matter $\left(\mathrm{PN}_{\mathrm{susp}}\right)$ were collected daily in each mesocosm and the lagoon for stable isotope analysis, to provide baseline $\delta^{15} \mathrm{~N}$ values for the pool of particles available for zooplankton grazing. Discrete water samples were collected daily from $6 \mathrm{~m}$ depth and filtered onto pre-combusted $25 \mathrm{~mm}$ GF/F filters. $\delta^{15} \mathrm{~N}$ values were determined by high-temperature combustion coupled with isotope ratio mass spectrometry using a Delta Plus Thermo Fisher Scientific mass spectrometer (Knapp et al., 2015).

\subsection{Zooplankton DNA extraction and quantitative PCR (qPCR)}

Individual copepods were picked from each filter and identified to order (calanoid, harpacticoid, or cyclopoid). Copepods were then placed in autoclaved artificial seawater (ASW) and visually inspected under a dissecting microscope for contamination from phytoplankton and detritus particularly in the mouthparts and appendages. Large particles were picked clean from the mouthparts and appendages with $20 \mu \mathrm{m}$ Minutien pins (Fine Science Tools, Foster City, CA, USA) before subsequently rinsing through five sterile baths of autoclaved ASW water and a final inspection under an epifluorescence microscope equipped with blue (450$490 \mathrm{~nm}$ ) and green $(510-560 \mathrm{~nm})$ excitation filters (Boling et al., 2012). Number of copepods and composition varied with each tow and can be found in Table 1. Aside from the day 5 samples from M1, where copepods were extracted by order, all copepods per sample were pooled together for extraction. DNA extraction was performed with the Qiagen DNeasy ${ }^{\circledR}$ Blood and Tissue Kit using slight modifications to the manufacturers "Animal Tissue (Spin-Column)" protocol. An overnight (12 h) lysis step was performed, all reagent volumes were $50 \%$ of the manufacturer's suggestions, and the final elution volume was $35 \mu \mathrm{L}$ in the provided "Buffer AE."

For the qPCR assays, we used the TaqMan primers and probes described by Church et al. (2005) for Trichodesmium spp., het-1 (Richelia associated with the diatom Rhizosolenia) and het-2 (Richelia associated with the diatom Hemiaulus), and unicellular group C (UCYN-C) primers and probes described by Foster et al. (2007). The four target diazotrophs were selected based on their being the most abundant $\mathrm{N}_{2}$ fixers throughout the mesocosm experiment (TurkKubo et al., 2015). For all TaqMan PCR, the $20 \mu \mathrm{L}$ reactions contained $10 \mu \mathrm{L}$ of $2 X$ Fast Advanced Master Mix (Applied Biosystems, Stockholm, Sweden), $5.5 \mu \mathrm{L}$ of nucleasefree water, $1.0 \mu \mathrm{L}$ each of Forward and Reverse Primer $\left(0.5 \mu \mathrm{mol} \mathrm{L}{ }^{-1}\right), 0.5 \mu \mathrm{L}$ of fluorogenic probe $\left(0.25 \mu \mathrm{mol} \mathrm{L}^{-1}\right)$, and $2 \mu \mathrm{L}$ of template. Each reaction was performed in triplicate and $2 \mu \mathrm{L}$ of no template controls (NTCs) was run. All PCR amplifications were conducted in an ABI Step One Plus system (Applied Biosystems) with the following parameters: $50^{\circ} \mathrm{C}$ for $2 \mathrm{~min}, 95^{\circ} \mathrm{C}$ for $20 \mathrm{~s}$, and 40 cycles of $95^{\circ} \mathrm{C}$ for $1 \mathrm{~s}$, followed by $60^{\circ} \mathrm{C}$ for $20 \mathrm{~s}$. Gene copy abundances were calculated from the mean number of cycle $\left(\mathrm{C}_{t}\right)$ of the three replicates and the standard curve for the appropriate primer and probe set (see below). In samples where one or two of the three replicates produced an amplification signal, these are noted as detectable but not quantifiable.

For each primer and probe set, duplicate standard curves were made from 10 -fold dilutions ranging from 1 to $10^{8}$ copies per reaction. The standards curves were synthesized 359 bp gene fragments (gBlocks, Integrated DNA Technologies, Leuven, Belgium) of the nifH gene. Regression analyses of the number of cycles $\left(C_{t}\right)$ of the standard curves were calculated in Excel.

\subsection{Zooplankton uptake and incorporation of diazotroph nitrogen: ${ }^{15} \mathrm{~N}_{2}$ labelled grazing experiments}

Uptake and incorporation of diazotroph nitrogen by zooplankton was assessed by a series of three ${ }^{15} \mathrm{~N}_{2}$ labelling experiments (Fig. 1). Each experiment consisted of ${ }^{15} \mathrm{~N}_{2}$ labelled bottle incubations of freshly collected zooplankton in the presence of natural phytoplankton assemblages. The ${ }^{15} \mathrm{~N}_{2}$ label was taken up by the diazotroph in the incubation bottle and used as a marker of zooplankton diazotroph ingestion. For each experiment (E1, E2, and E4), zooplankton was collected after sunset (18:00-19:00 GMT +11$)$ by repeated $1 \mathrm{~m} \mathrm{~s}^{-1}$ vertical hauls with the same net used for daytime zooplankton collections (see above), in close proximity to the mesocosms site. Live zooplankton were collected with a $64 \mu \mathrm{m}$ sieve and placed in three $25 \mathrm{~L}$ polycarbonate carboys (two net tows per carboy) filled with seawater collected using a Teflon pump (Saint-Gobain Performance Plastics) from M1 (1 m depth) on day 12 for experiment E1, during a DDA-dominated period ( $>80 \%$ of diazotroph community comprised Richelia associated with Rhizosolenia, i.e. het-1); from M2 (1 m depth) on day 17 for experiment E2, during a UCYN-C bloom (comprising $>80 \%$ of diazotroph community); and from lagoon waters (1 m depth) on day 23 for E4 during a Trichodesmium spp. bloom (comprising $>80 \%$ of diazotroph community; Turk-Kubo et al., 2015). Although each experiment was $>80 \%$ dominated by a single diazotroph species, it must be noted that each contained other diazotroph species. Carboys were filled to the top, leaving no head space, and tightly closed with septum caps. Carboys were immediately amended with $26 \mathrm{~mL}^{15} \mathrm{~N}_{2}$ gas (Cambridge isotopes, 98.9 at. $\%{ }^{15} \mathrm{~N}$ ) using a gas-tight syringe, gently agitated 20 times to facilitate the ${ }^{15} \mathrm{~N}_{2}$ bubble 
Table 1. Summary of copepod samples processed for qPCR, targeting Trichodesmium spp., het-1 and the het-2 (DDA), and unicellular group $\mathrm{C}$ (UCYN-C). All copepods per sample were pooled during the DNA extraction protocol. Site refers to the three VAHINE mesocosms (M13) and the lagoon waters (La). Samples V3-V4 were from the period prior to phosphorous fertilisation (P0; days 0-04); samples V10-V26 were from the period dominated by DDA (het-1) (P1; days 5-14); samples V34-V52 were from the period dominated by UCYN-C (P2; days 15-23). Het-1 is Richelia associated with Rhizosolenia; het-2 is Richelia associated with Hemiaulus; bd is below detection; dnq is detectable but not quantifiable; number in parenthesis is number of targets hit in three replicates.

\begin{tabular}{|c|c|c|c|c|c|c|c|c|c|c|}
\hline $\begin{array}{l}\text { Sample } \\
\text { ID }\end{array}$ & Day & Site & $\begin{array}{r}\text { Total no. } \\
\text { copepods }(n)\end{array}$ & $\begin{array}{r}\text { Calanoid } \\
(n)\end{array}$ & $\begin{array}{r}\text { Cyclopoid } \\
(n)\end{array}$ & $\begin{array}{r}\text { Harpacticoid } \\
(n)\end{array}$ & $\begin{array}{l}\text { Het-1 nifH } \\
\text { copies/copepod }\end{array}$ & $\begin{array}{l}\text { Het-2 nifH } \\
\text { copies/copepod }\end{array}$ & $\begin{array}{l}\text { Trichodesmium } \\
\text { nifH copies/copepod }\end{array}$ & $\begin{array}{l}\text { UCYN-C nifH } \\
\text { copies/copepod }\end{array}$ \\
\hline V3 & 2 & M2 & 35 & 13 & 13 & 9 & 173.31 & 62.14 & 264.4 & dnq (1) \\
\hline V4 & 2 & $\mathrm{La}$ & 22 & 10 & 7 & 5 & bd & dnq (1) & bd & bd \\
\hline V10 & 5 & M3 & 21 & 11 & 7 & 3 & bd & bd & bd & bd \\
\hline V11 & 5 & M2 & 7 & 2 & 3 & 2 & bd & bd & bd & bd \\
\hline V17 & 9 & M3 & 20 & 12 & 6 & 2 & dnq (1) & bd & bd & dnq (1) \\
\hline V18 & 9 & M2 & 31 & 10 & 16 & 5 & dnq (1) & bd & bd & dnq (2) \\
\hline V20 & 9 & $\mathrm{La}$ & 26 & 10 & 13 & 3 & 16.52 & bd & bd & bd \\
\hline V25 & 12 & M3 & 22 & 7 & 10 & 5 & dnq (1) & bd & bd & bd \\
\hline V26 & 12 & M2 & 29 & 11 & 9 & 9 & 34.83 & $\operatorname{dnq}(1)$ & bd & dnq (1) \\
\hline V34 & 16 & M2 & 18 & 5 & 8 & 6 & 181.37 & $\mathrm{n} / \mathrm{a}$ & 277.94 & 6.48 \\
\hline V35 & 16 & M1 & 21 & 10 & 9 & 2 & bd & bd & dnq (1) & $\operatorname{dnq}(2)$ \\
\hline V36 & 16 & $\mathrm{La}$ & 31 & 16 & 12 & 3 & 128.92 & bd & dnq (1) & dnq (1) \\
\hline V41 & 19 & M3 & 27 & 15 & 9 & 3 & 26.84 & bd & dnq (1) & $\operatorname{dnq}(2)$ \\
\hline V44 & 19 & $\mathrm{La}$ & 42 & 35 & 6 & 1 & $\operatorname{dnq}(2)$ & bd & bd & $\operatorname{dnq}(1)$ \\
\hline V50 & 23 & M2 & 12 & 7 & 3 & 2 & bd & bd & bd & $\operatorname{dnq}(2)$ \\
\hline V51 & 23 & M1 & 11 & 6 & 4 & 1 & bd & bd & bd & 28.72 \\
\hline V52 & 23 & $\mathrm{La}$ & 20 & 9 & 4 & 7 & dnq (1) & bd & $\operatorname{dnq}(2)$ & 4.58 \\
\hline
\end{tabular}

dissolution, and incubated in situ on a mooring line close to the mesocosms site at the sampling depth $(1 \mathrm{~m})$ for $24-96 \mathrm{~h}$.

Zooplankton T0 atomic enrichment was measured in triplicate for E1 and the average value was used as the baseline for $\mathrm{E} 1, \mathrm{E} 2$, and $\mathrm{E} 4$. Incubation termination times were 24, 48 , and $72 \mathrm{~h}$ for $\mathrm{E} 1 ; 24,72$, and $96 \mathrm{~h}$ for $\mathrm{E} 2 ; 24$ and $40 \mathrm{~h}$ for E4 (Table 2). After incubation, animals were recovered from each carboy by gravity filtration onto a $64 \mu \mathrm{m}$ mesh sieve, transferred to a $20 \mu \mathrm{m}$ polycarbonate filter, and frozen until the end of the VAHINE experiment. Subsequently, the zooplankton on the filters were identified to order and enumerated under a stereo microscope (Table 2) before being dried at $24 \mathrm{~h}$ at $60^{\circ} \mathrm{C}$. In all cases, composition comprised an $87-100 \%$ mix of poecilostomatoid and calanoid copepods. All individuals from each time point were pooled for measurement of bulk zooplankton PON ${ }^{15} \mathrm{~N}$ enrichment, using a Delta Plus Thermo Fisher Scientific isotope ratio mass spectrometer (Bremen, Germany) coupled with an elemental analyzer (Flash EA, Thermo Fisher Scientific). Since the role of the microbial loop in making diazotroph nitrogen available to the zooplankton was not determined, the experiments are indicative of diazotroph nitrogen uptake and incorporation by the zooplankton but not necessarily the pathways.

The atomic enrichment of the dominant diazotrophs during each experiment were measured after $24 \mathrm{~h}$ incubation in a parallel experiment, using the same enrichment procedure as the zooplankton grazing experiment, designed to trace the fate of DDN in phytoplankton (Berthelot et al., 2015b; Bonnet et al., 2016a, c). Accordingly, atomic enrichment was ob- tained for UCYN-C (E2) and Trichodesmium spp. (E4), but not for DDA (E1).

\subsection{Statistical analyses}

A sample by taxon matrix was created using taxon-specific densities. Densities were fourth root transformed and the percentage similarity between stations from all surveys was calculated using the Bray-Curtis similarity index (Field et al., 1982). The similarity matrix was then ordinated using nonmetric multidimensional scaling (NMDS), summarizing between sample variation in community composition into two dimensions. This multivariate analyses were performed using PRIMER 6 (Clarke and Warwick, 2001). The NMDS had a stress value of 0.23 . The first two dimensions of the ordination were plotted against sampling date for each mesocosm and the lagoon site to enable visual assessment of the change in zooplankton composition over the course of the experiment.

\subsection{Calculation of DDN contribution to zooplankton biomass}

The contribution of DDN (\%) to zooplankton $\delta^{15} \mathrm{~N}$ (ZDDN) values in each sample collected during this study was calculated using a two-source mixing model following Sommer et al. (2006):

$$
\% \mathrm{ZDDN}=100 \times\left(\frac{\delta^{15} \mathrm{~N}_{\mathrm{zpl}}-\delta^{15} \mathrm{~N}_{\mathrm{zplref}}}{\mathrm{TEF}+\delta^{15} \mathrm{~N}_{\text {diazo }}-\delta^{15} \mathrm{~N}_{\mathrm{zplref}}}\right),
$$


Table 2. Summary of three ${ }^{15} \mathrm{~N}_{2}$ labelled diazotroph grazing experiments, indicating number of zooplankton analysed per hourly time period.

\begin{tabular}{llllrrrr}
\hline & & & \multicolumn{5}{c}{ Number of zooplankton analysed } \\
\cline { 3 - 8 } Experiment & Day & $\begin{array}{l}\text { Dominant } \\
\text { diazotroph }\end{array}$ & $0 \mathrm{~h}$ & $24 \mathrm{~h}$ & $\begin{array}{r}48 \mathrm{~h} \\
(40 \mathrm{~h})\end{array}$ & $72 \mathrm{~h}$ & $96 \mathrm{~h}$ \\
\hline E1 & 12 & DDA & 70 & 45 & 36 & 15 & \\
E2 & 17 & UCYN-C & & 90 & & 57 & 28 \\
E4 & 23 & Trichodesmium spp. & 37 & $(15)$ & & \\
\hline
\end{tabular}

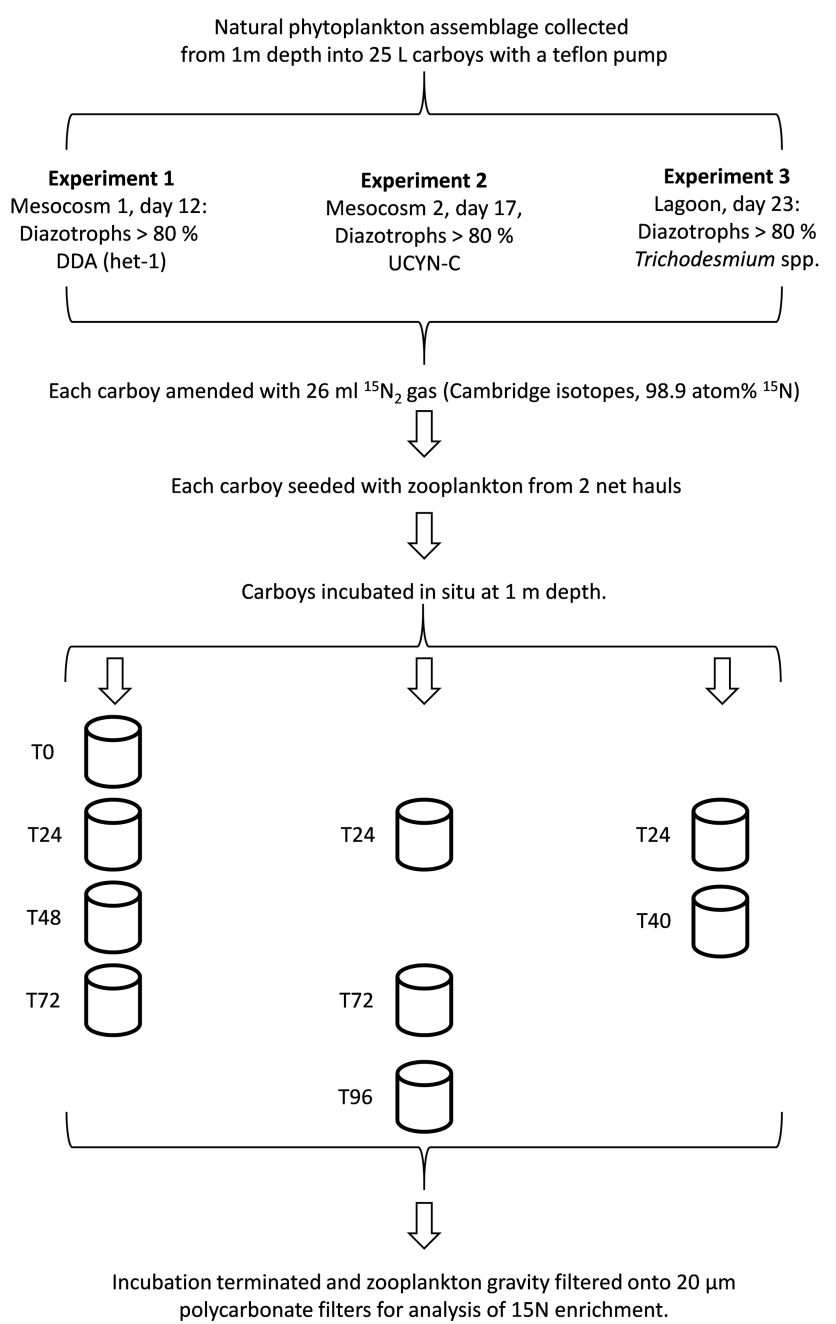

Figure 1. Schematic of field ${ }^{15} \mathrm{~N}_{2}$ incubations to measure zooplankton uptake and incorporation of diazotroph nitrogen.

where $\delta^{15} \mathrm{~N}_{\mathrm{zpl}}$ is the isotopic signature of the zooplankton collected during the experiment; TEF is the trophic enrichment factor, which was set at $2.2 \pm 0.3 \%$ o (McCutchan et al., 2003; Vanderklift and Ponsard, 2003); $\delta^{15} \mathrm{~N}_{\text {diazo }}$ is the isotopic signature of diazotrophs, for which we used a range of -1 to $-2 \%$ o (Montoya et al., 2002); $\delta^{15} \mathrm{~N}_{\text {zplref }}$ is the isotopic signature of zooplankton assuming nitrate-based phytoplank- ton production, and for this we used a value of $6 \%$ from the ocean west of New Caledonia where nitrogen fixation is reduced (Hunt et al., 2015). Minimum, average, and maximum $\%$ ZDDN were estimated using the lower, mean, and upper bounds of TEF and the $\delta^{15} \mathrm{~N}_{\text {diazo }}$ values cited above. Daily DDN production ingested by the zooplankton each day (mg dry weight day ${ }^{-1}$ ) was calculated as follows:

$$
\begin{aligned}
\text { daily DDN ingested } \text { day }^{-1} & =\left(\frac{\mathrm{N} \text { production }+\mathrm{N} \text { excretion }}{\text { assimilation efficiency }}\right) \\
& \times \% \mathrm{ZDDN},
\end{aligned}
$$

where $\mathrm{N}$ content (mg DW) was calculated using a mean value of $4.25 \%$ for a mixed zooplankton community in the Uvea lagoon (Le Borgne et al., 1997); daily zooplankton production ( $\mathrm{mg} \mathrm{DW} \mathrm{d}^{-1}$ ) was calculated using a production-tobiomass ratio of $37.5 \%$ (Le Borgne, 1987); daily excretion was calculated assuming a net growth efficiency (K) of 0.513 (Le Borgne et al., 1997); and assimilation efficiency was set at 0.7 (Le Borgne et al., 1997). The range of daily DDN production ingested by zooplankton was estimated using the calculated minimum, average, and maximum \% ZDDN values. Finally, we estimated the percentage of daily DDN production consumed by zooplankton as follows:

$\%$ daily DDN production ingested day ${ }^{-1}=$

$100 \times\left(\frac{\text { daily DDN ingested } \text { day }^{-1}}{\text { daily DDN production }}\right)$.

Daily DDN production ( $\mathrm{N}_{2}$ fixation) was calculated from the mean of the three measurement depths in each mesocosm over the course of the experiment (Berthelot et al., 2015b).

\section{Results}

\subsection{Environmental context}

Briefly, seawater temperature increased inside the mesocosms and in Noumea lagoon waters from 25.5 to $26.2^{\circ} \mathrm{C}$ over the course of the experiment. The water column was well mixed in the mesocosms as temperature and salinity were homogeneous with depth over the course of the experiment (Bonnet et al., 2016b). Prior to the DIP fertilization on day 4 (hereafter called P0), DIP concentrations in the 
mesocosms ranged from 0.02 to $0.05 \mu \mathrm{mol} \mathrm{L}^{-1}$ (Berthelot et al., 2015b). The day after the fertilization, DIP concentrations were $\sim 0.8 \mathrm{mmol} \mathrm{L}^{-1}$ in all mesocosms. Subsequently the concentrations decreased steadily towards initial concentrations by the end of the experiment. Depth-averaged nitrate + nitrite concentrations were below $0.04 \mu \mathrm{mol} \mathrm{L}^{-1}$ the day before DIP fertilization and decreased to $0.01 \mu \mathrm{mol} \mathrm{L} \mathrm{L}^{-1}$ towards the end of the experiment. In lagoon waters, nitrate + nitrite remained below $0.20 \mu \mathrm{mol} \mathrm{L}^{-1}$ and DIP averaged $0.05 \mu \mathrm{mol} \mathrm{L}^{-1}$ throughout the experiment.

Bulk $\mathrm{N}_{2}$ fixation rates averaged $18.5 \pm 1.1 \mathrm{nmol} \mathrm{NL}^{-1} \mathrm{~d}^{-1}$ over the 23 days of the experiment in the three mesocosms (all depths averaged together; Bonnet et al., 2016a). Rates increased significantly in the mesocosms over the course of the experiment to reach an average of $27.3 \pm 1.0 \mathrm{nmolNL}^{-1} \mathrm{~d}^{-1}$ during the second half of the experiment (days 15-23, hereafter called P2; Bonnet et al., 2016a). $\mathrm{N}_{2}$ fixation rates measured in the lagoon waters were significantly $(p<0.05)$ lower than rates measured in the mesocosm and remained relatively consistent over the 23 days of the experiment $\left(9.2 \pm 4.7 \mathrm{nmol} \mathrm{N} \mathrm{L}^{-1} \mathrm{~d}^{-1}\right)$.

The diazotroph assemblage in the lagoon on the day that the mesocosm experiment was initiated was composed primarily of DDAs (het-1: Richelia associated with Rhizosolenia; and het-2: Richelia associated with Hemiaulus) and the symbiotic UCYN-A2 and A1 (Turk-Kubo et al., 2015). Trichodesmium spp. and UCYN-C were minor components, and at least an additional three phylotypes were present, including one heterotrophic diazotroph. The abundance and community of diazotrophs changed extensively in the mesocosms over the course of the experiment. From day 1 to day 4, a shift in the starting community was observed in the mesocosms. Het-1 remained the most abundant diazotroph; however, UCYN-A2 abundances decreased and Trichodesmium spp. abundances increased with respect to their abundances in the lagoon, while UCYN-C remained at low abundance levels. After DIP fertilization, from day 5 to day 14 (hereafter called P1), the abundance of het-1 increased. Following day 15 , the community shifted towards dominance of UCYN-C, the abundance of which increased substantially during P2 (Turk-Kubo et al., 2015). Het-1 was the dominant diazotroph in the lagoon waters where a Trichodesmium spp. bloom began to develop during P2, after day 20 (Turk-Kubo et al., 2015). Chlorophyll $a$ (Chl $a$ ) biomass was $<0.3 \mu \mathrm{g} \mathrm{L}^{-1}$ in all three mesocosms during P0 and P1 (Leblanc et al., 2016). During P2, Chl $a$ increased in all the mesocosms, but particularly M3, reaching maximum depth-averaged concentrations of $0.55,0.47$, and $1.29 \mu \mathrm{g} \mathrm{L}{ }^{-1}$ in M1, M2, and M3, respectively. Lagoon Chl $a$ followed a similar pattern to the mesocosms, being $<0.3 \mu \mathrm{g} \mathrm{L}^{-1}$ during the $\mathrm{P} 0$ and $\mathrm{P} 1$ timeframe, and increasing to a lower extent to $0.42 \mu \mathrm{g} \mathrm{L}{ }^{-1}$ during P2.
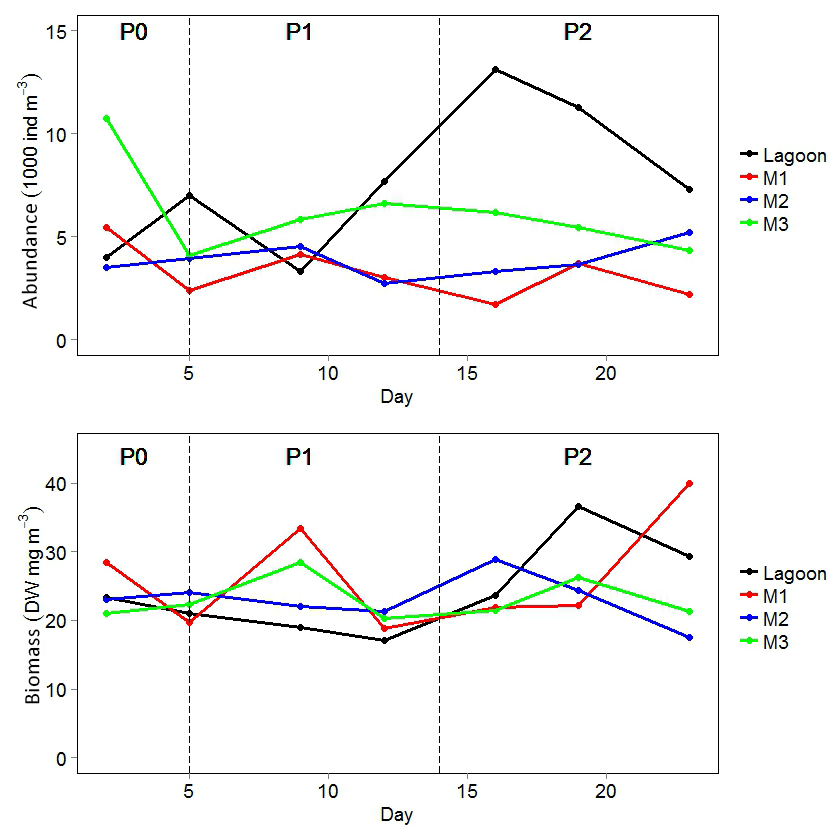

Figure 2. Zooplankton abundance (ind $\mathrm{m}^{-3}$; above) and biomass (mg DW m${ }^{-3}$; below) over the 23-day VAHINE experiment (13 January to 4 February 2013) for the three VAHINE mesocosms (M1-3) and the lagoon waters. P0, P1, and P2 refer to the pre-phosphorous fertilization, DDA-dominated, and UCYN-Cdominated periods of the experiment, respectively.

\subsection{Zooplankton community and stable isotope composition}

Zooplankton abundance at the start of the experiment averaged $\sim 5000$ ind $^{-3}$ in lagoon waters, M1, and M2, while it was 10735 ind $^{-3}$ in M3 (Fig. 2). Over the course of the experiment abundance in M1 and M2 ranged between 5425 and 1741 ind $^{-3}$. M1 densities had a slight declining trend, while M2 densities were relatively stable, even increasing towards the end of the experiment. In M3, zooplankton abundance was consistently higher than M1 and M2 though declining after day 12 from 6618 to

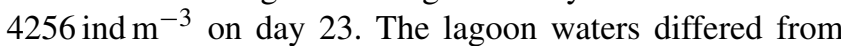
the mesocosms with zooplankton abundance levels increasing to peak at 13113 ind $\mathrm{m}^{-3}$ on day 16 , before declining to $\sim 7300$ ind $\mathrm{m}^{-3}$ on day 23 . Zooplankton had a mean biomass of $24 \mathrm{mg} \mathrm{DW} \mathrm{m}^{-3}$ and ranged between 17.2 and $40 \mathrm{mg} \mathrm{DW} \mathrm{m}^{-3}$ (Fig. 2). No consistent temporal pattern in zooplankton biomass was detected over the course of the experiment.

The zooplankton community was dominated by copepod nauplii at all sites, with the exception of day 2 at M2 when poecilostomatoids dominated and day 9 at M1 when appendicularians dominated (Fig. 3). Copepod nauplii contributed an average of $51 \%$ to total abundance $\left(2784\right.$ ind $\left.^{-3}\right)$. Appendicularians were the next most abundant group, contributing an average of $15.1 \%$ to total abun- 


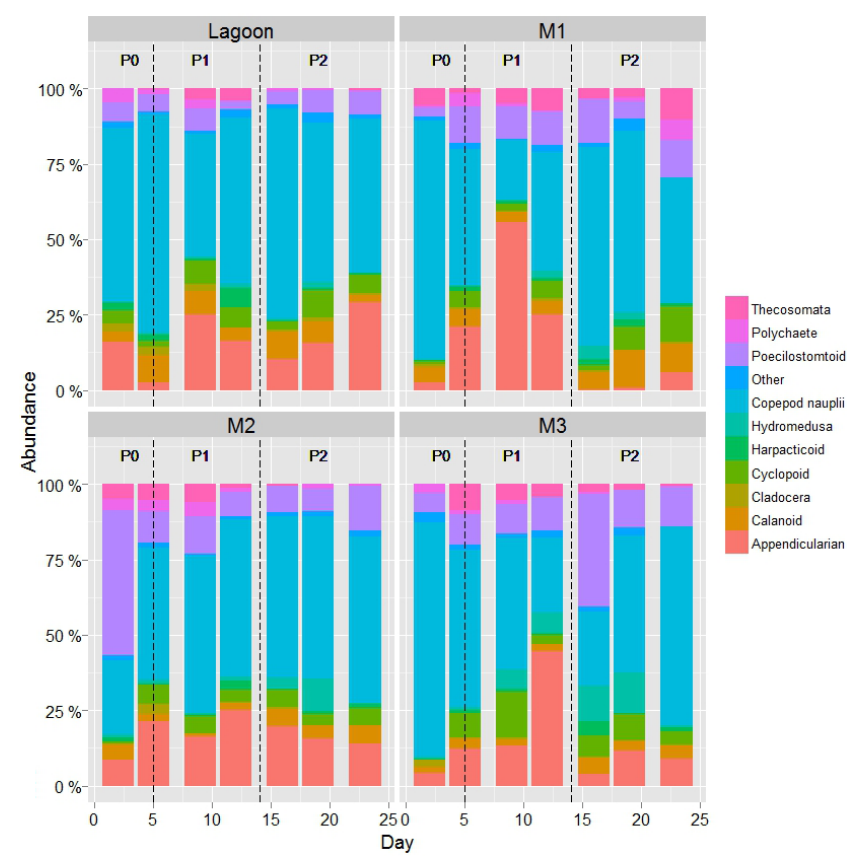

Figure 3. Proportional composition of zooplankton groups to total zooplankton abundance in the three VAHINE mesocosms (M1-3) and the lagoon waters.

dance $\left(801 \mathrm{ind}^{-3}\right.$ ), followed by poecilostomatoid copepods at $11.5 \%\left(541 \mathrm{ind} \mathrm{m}^{-3}\right)$. Peaks in appendicularian abundance were observed during P1 in M1 and M3. Cyclopoid, calanoid, and harpacticoid copepods contributed $5.5,5$, and $1.4 \%$ to total abundance, respectively. Although the proportional contributions of these groups was low, their abundance levels were relatively high, averaging 276, 265, and $72 \mathrm{ind}^{-3}$ for cyclopoid, calanoid, and harpacticoids, respectively.

Bray-Curtis similarity levels among samples exceeded $70 \%$ in all cases with the exception of the day 19 control sample $(\sim 65 \%)$. This is on the high range of similarity for zooplankton communities (Hunt et al., 2008). The first dimension of the NMDS was most variable over the course of the experiment, and between site variability was highest on day 2 (Fig. 4). Subsequent to day 2, NMDS scores for the three mesocosms converged, with M1 and M2 having the greatest similarity. The NMDS scores for dimension 1 in all mesocosms diverged from the lagoon waters after day 9. The opposite directional trends of the mesocosms versus the lagoon waters was driven primarily by changes in abundance levels of the same pool of species.

Zooplankton $\delta^{15} \mathrm{~N}$ values averaged 4.9, 4.2, 4.8, and 5.2\%o in lagoon waters, M1, M2, and M3, respectively (Fig. 5). Zooplankton $\delta^{15} \mathrm{~N}$ values were relatively consistent over the course of the experiment in M2 and M3. In M1, zooplankton $\delta^{15} \mathrm{~N}$ values decreased from a mean of $5 \%$ o between days 2 and 12 (P0 and P1) to a mean of $3.2 \%$ o from day 16 to day 23 (P2). In lagoon waters, a decline in zooplankton $\delta^{15} \mathrm{~N}$ values
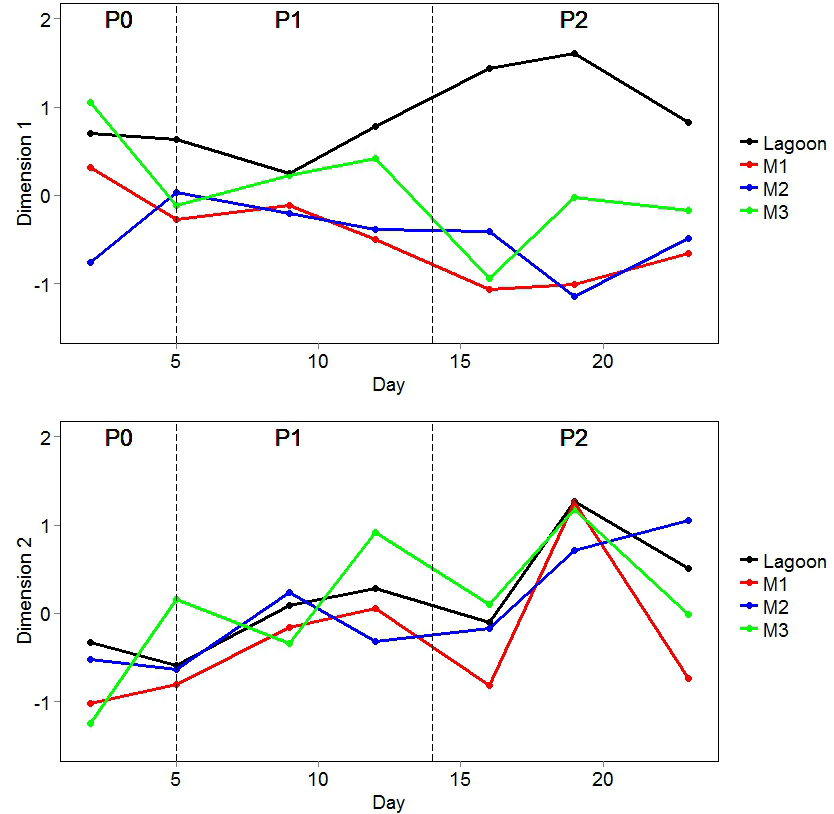

Figure 4. Zooplankton community NMDS ordination scores (dimension 1 above and dimension 2 below), based on Bray-Curtis similarity of fourth root transformed abundance data, over the 23day VAHINE experiment (13 January-4 February 2013) for the three VAHINE mesocosms (M1-3) and the lagoon waters. P0, P1, and $\mathrm{P} 2$ refer to the pre-phosphorous fertilization, DDA-dominated, and UCYN-C-dominated periods of the experiment, respectively.

were evident over the course of the experiment, from $6.0 \%$ o on day 5 to $4.4 \%$ on day 23 .

The $\delta^{15} \mathrm{~N}$ value of $\mathrm{PN}_{\text {susp }}$ was more variable than the zooplankton, commensurate with the expected higher cellular turnover rates of the $\mathrm{PN}_{\text {susp }}$ constituents relative to zooplankton. In $\mathrm{M} 3, \mathrm{PN}_{\text {susp }} \delta^{15} \mathrm{~N}$ values increased to the same level as the zooplankton on day 11 and remained at that level until the end of the experiment. An increase in $\mathrm{PN}_{\text {susp }} \delta{ }^{15} \mathrm{~N}$ values to above zooplankton levels was observed in lagoon waters and M2 after day 20. Zooplankton $\delta^{15} \mathrm{~N}$ values averaged $1.2 \%$ o higher than $\mathrm{PN}_{\text {susp }}$ across all sites, less than the expected $2.2 \%$ one trophic level difference between the $\mathrm{PN}_{\text {susp }}$ and zooplankton.

The percent contribution of DDN to zooplankton biomass averaged $24 \%$ (range is 4-86\%) in the mesocosms and $21 \%$ (range is $0-39 \%$ ) in the lagoon waters (Fig. 6) over the 23day experiment. The highest average contribution of DDN to zooplankton was measured in M1 on day $16(73 \%)$. The contribution of DDN to zooplankton biomass in M2 and the lagoon increased steadily from $\sim 10 \%$ in the middle of $\mathrm{P} 1$ (day 9) to $>30 \%$ by the end of the experiment. An initial increase in the contribution of DDN to zooplankton biomass was observed in M1 and M3 after day 9 until day 16, after which it declined until the end of the experiment despite these mesocosms having the highest $\mathrm{N}_{2}$ fixation rates (Bonnet et al., 2016a). 


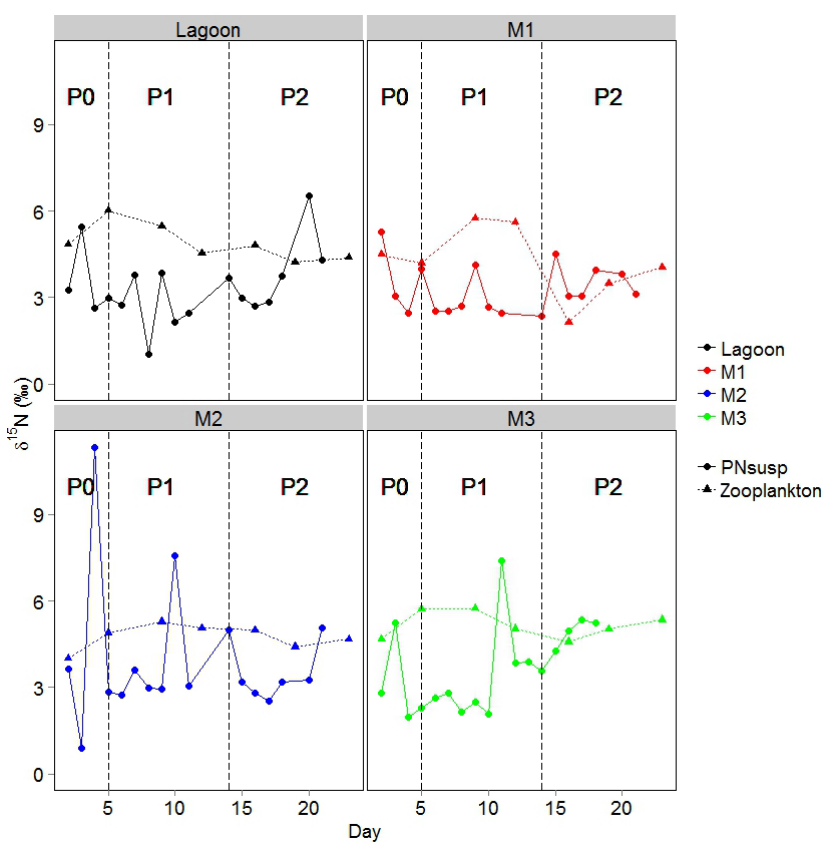

Figure 5. Nitrogen isotope $\left(\delta^{15} \mathrm{~N}\right)$ values of zooplankton and suspended particulate nitrogen $\left(\mathrm{PN}_{\text {susp }}\right)$ over the course of the 23-day VAHINE experiment (13 January-4 February 2013) for the three VAHINE mesocosms (M1-3) and the lagoon waters. P0, P1, and $\mathrm{P} 2$ refer to the pre-phosphorous fertilization, DDA-dominated, and UCYN-C-dominated periods of the experiment, respectively. Zooplankton values are indicated by a solid line and $\mathrm{PN}_{\text {susp }}$ by a dashed line.

Estimated daily DDN production ingested by the zooplankton initially declined in the mesocosm and lagoon, and remained comparatively low in M1 and M3, while increasing in M1 and the lagoon after day 9 (Fig. 6). The estimated percent of daily DDN production ingested was generally high, averaging $\sim 240 \%$. This difference between estimated DDN ingestion and measured DDN production likely reflects the longer integration time of stable isotope measurements and accumulation of the DDN signature in the zooplankton over multiple days (Montoya et al., 2002).

\section{3 qPCR analysis of direct zooplankton grazing on diazotrophs}

Results from the qPCR are summarized in Table 1. In general, the qPCR was successful in amplifying and detecting the four different targets (het-1, het-2, Trichodesmium spp., and UCYN-C) in the copepods collected during the mesocosm experiment. Poor detection was listed as either below detection (bd) or detectable but not quantifiable (dnq; see Methods).

Of all the oligonucleotides tested, the het- 2 and Trichodesmium spp. targets were the least detected. However, when het- 2 and Trichodesmium spp. targets were detected, the abundance was high, e.g. 62.1 and 264.4 nifH
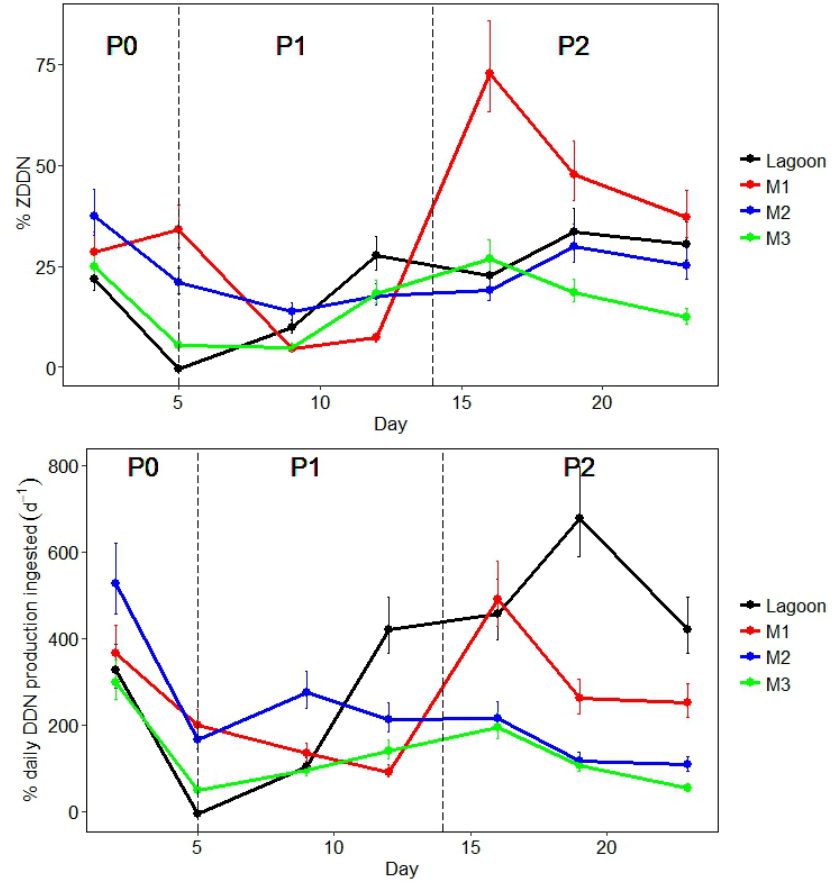

Figure 6. Average percent contribution of diazotroph-derived nitrogen (DDN) to zooplankton biomass (above) and estimated average percent of fixed nitrogen ingested by zooplankton day ${ }^{-1}$ over the course of the 23-day VAHINE experiment (13 January-4 February 2013) for the three mesocosms (M1-3) and the lagoon waters. $\mathrm{P} 0, \mathrm{P} 1$, and $\mathrm{P} 2$ refer to the pre-phosphorous fertilization, DDAdominated, and UCYN-C-dominated periods of the experiment, respectively. Error bars in the upper panel represent the minimum and maximum values of $\%$ ZDDN calculated using a trophic enrichment factor range of $2.2 \pm 0.3 \%$ (McCutchan et al., 2003; Vanderklift and Ponsard, 2003) and diazotroph $\delta^{15} \mathrm{~N}$ value range of -1 to $-2 \%$ (Montoya et al., 2002). The error bars in the lower panel reflect the range of percent DDN production ingested by zooplankton using the range of percent ZDDN.

copies/copepod, respectively, in M2 during P0 (day 2). Subsequently, het-2 detection was bd for the remainder of the experiment, with the exception of two dnq samples, one from the lagoon during $\mathrm{P0}$ (day 2) and another from M2 towards the end of P1 (day 12). Trichodesmium spp. targets were bd after day 2, until 277.9 nifH copies/copepod was quantified from a M2 sample on day 16. Overall, Trichodesmium spp. was more prevalent during $\mathrm{P} 2$, being quantifiable or dnq in five of nine samples. Het-1 and UCYN-C were higher in detection, each being bd in only 6 of the 19 samples tested. Het-1 targets were the most frequently detected, occurring at high abundance (16.5-173.3 nifH copies/copepod) in all of the mesocosms and lagoon waters during P1 and the beginning of P2, but were bd or dnq after day 19. UCYN-C was detected most frequently and at highest abundance during P2, corresponding with this groups' peak occurrence in the mesocosms. 


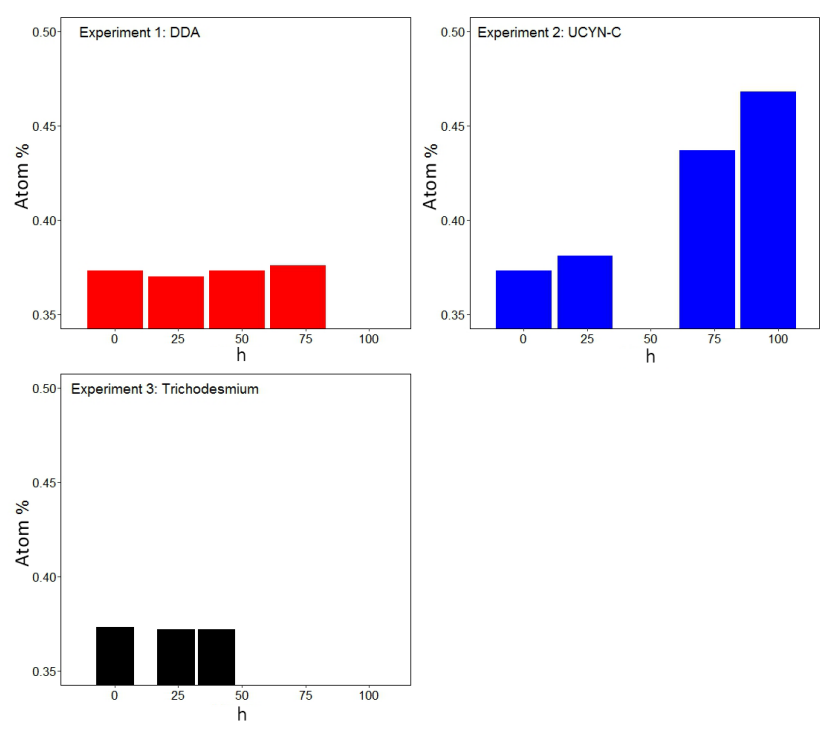

Figure 7. Atomic percent of enrichment of zooplankton in three ${ }^{15} \mathrm{~N}_{2}$ labelled diazotroph grazing experiments. The dominant diazotrophs in Experiments 1, 2, and 4 were DDA (het-1: Richelia associated with Rhizosolenia), UCYN-C, and Trichodesmium spp., respectively. Zooplankton T0 atomic percent of enrichment was measured in triplicate for E1 and the average value was used as the baseline for E1, E2, and E4. The atomic percent of enrichment of the diazotroph community after $24 \mathrm{~h}$ was $1.515 \%$ for UCYN-C and $0.613 \%$ for Trichodesmium spp. No enrichment value was obtained for DDA.

\subsection{Zooplankton incorporation of diazotroph nitrogen}

After $24 \mathrm{~h}$ incubation, the atomic enrichment of UCYN-C was 1.515 at. \% and Trichodesmium spp. 0.613 at. \%. No direct measurement of atomic enrichment was obtained from DDA. The average atomic enrichment of zooplankton at $T=$ 0 in $\mathrm{E} 1$ was $0.373 \pm 0.005$ at. \%. This T0 value was applied as the baseline for E2 and E4. Zooplankton showed weak atomic enrichment over the course of E1 (het-1-dominated diazotroph community) and none over the course of E4 (Trichodesmium spp.-dominated diazotroph community; Fig. 7). Conversely, a large increase of $\sim 0.1$ at. $\%$ was measured over the course of E2 (UCYN-C-dominated diazotroph community). It should be noted that zooplankton were not allowed to purge their stomach contents after the incubation experiments, and this may have been a source of overestimation of diazotroph nitrogen incorporation. However, the persistent increase during E2 does indicate that diazotroph nitrogen incorporation was the primary factor in observed atomic enrichment. Although E1 and E4 were of shorter duration than E2, discernable atomic enrichment was measured in E2 even after $24 \mathrm{~h}$. The only instance where the dominant diazotroph in the water collected on the day of experiment initiation was also detected in high abundance in copepod guts on or within 1 day of this water collection was E2/UCYN-C (Table 1; Fig. 7). Trichodesmium spp. was dnq in copepod guts on day 23 in the lagoon (E4), while there was no evidence of het-1 in copepod guts on day 12 (E2).

\section{Discussion}

The zooplankton biomass sampled during VAHINE, both inside the mesocosms and in lagoon waters, was is the normal range for the New Caledonian lagoon (Le Borgne et al., 2010 ). Over the course of the experiment $\sim 28 \%$ of the total volume of each mesocosm was sampled. An additional $2-5 \%$ of the zooplankton community was lost to the mesocosm sediment traps and qualified as swimmers (Berthelot et al., 2015b). These two sources of losses likely accounted for the slight declining trend in abundance in M1 and M2, and M3 after day 12. Despite the divergence of lagoon waters and mesocosms abundance levels over the course of the experiment, a high level of similarity ( $>70 \%$ ) was maintained in the community composition among sites, indicating that the mesocosm zooplankton communities remained largely representative of the natural lagoon conditions. On average, this community comprised $63 \%$ copepods, with the next highest community contributor being appendicularians $(\sim 15 \%)$. Harpacticoid copepods, which have previously been noted as important diazotroph grazers, contributed $<1.5 \%$ on average.

The $\delta^{15} \mathrm{~N}$ values of $\mathrm{PN}_{\text {susp }}$ over the course of the experiment was high in comparison to measurements from other areas of the world's oceans with significant $\mathrm{N}_{2}$ fixation (Altabet, 1988; Dore et al., 2002; Montoya et al., 2002). It has been noted that elevated $\delta^{15} \mathrm{~N}$ values of $\mathrm{PN}_{\text {susp }}$ in the New Caledonian lagoon may be influenced by island runoff, and particularly untreated sewage which typically has a $\delta^{15} \mathrm{~N}$ values of 5 to $20 \%$ (Cole et al., 2004). Although the VAHINE site was located $28 \mathrm{~km}$ from the coast, and strongly influenced by inflowing oceanic water, the elevated $\delta^{15} \mathrm{~N}$ values of $\mathrm{PN}_{\text {susp }}$, despite a high contribution of $\mathrm{N}_{2}$ fixation, indicated that the $\delta^{15} \mathrm{~N}$ values of $\mathrm{PN}_{\text {susp }}$ were influenced by landderived inputs (Knapp et al., 2015). Notably the $\delta^{15} \mathrm{~N}$ values of $\mathrm{PN}_{\text {susp }}$ did not show a decreasing trend over the course of the experiment, either inside or outside the mesocosms, even increasing in M3 during P2, despite the increasing $\mathrm{N}_{2}$ fixation rates in all mesocosms. In contrast, the $\delta^{15} \mathrm{~N}$ values of $\mathrm{PN}_{\text {susp }}$ settling in the sediment traps decreased with time from $4.2 \pm 0.2$ during $\mathrm{P} 0$, to $3.0 \pm 0.4$ during $\mathrm{P} 1$ and $2.3 \pm 0.9 \%$ o during P2 (Knapp et al., 2015). Indeed, it is estimated that the majority of the DDN that accumulated over the course of the experiment was exported to the sediment traps, either through direct sedimentation of diazotrophs or of nondiazotrophic phytoplankton that had taken up dissolved $\mathrm{N}$ sourced from the DDN pool (Bonnet et al., 2016a).

Overall, zooplankton $\delta^{15} \mathrm{~N}$ values in the mesocosms and lagoon tended to decline gradually over the course of the experiment, with the exception of M1 where a more marked decline was observed during P2. A similar, albeit shorter (9 
days), mesocosm study conducted in the Baltic Sea measured a rapid decrease in zooplankton $\delta^{15} \mathrm{~N}$ values in response to a Nodularia spumigena bloom (Sommer et al., 2006). In that study elevated zooplankton $\delta^{15} \mathrm{~N}$ values $(9.9 \%$ ) at the start of the experiment likely amplified the effect of DDN uptake. During VAHINE, zooplankton $\delta^{15} \mathrm{~N}$ values were $\sim 5.0 \%$ at the start of the experiment, and the estimated mean contribution of DDN to zooplankton biomass on day 2 was $\sim 28 \%$. As previously mentioned, diazotroph activity in the New Caledonian lagoon peaks in the summer months (Biegala and Raimbault, 2008; Le Borgne et al., 2010). A time series of monthly zooplankton samples collected between October 2012 and July 2014 reveals a seasonal summer depletion of $\delta^{15} \mathrm{~N}$ values in the New Caledonia lagoon (B. Hunt, unpublished data). It is therefore not surprising that a depletion in zooplankton $\delta^{15} \mathrm{~N}$ values was less marked during VAHINE, which took place during the summer season, despite the increase in $\mathrm{N}_{2}$ fixation rates observed at all sites through the experiment.

The gradual decline of zooplankton $\delta^{15} \mathrm{~N}$ values corresponded with the increased contribution of DDN to zooplankton biomass over the course of the experiment in both the mesocosms and lagoon, with the exception of M3. The peak DDN contribution to the zooplankton of $73 \%$, on day 16 in M1, was on the high end of values reported in the literature on the subtropical North Atlantic (Landrum et al., 2011). The average DDN contribution to the zooplankton at the start of the experiment $(\sim 28 \%)$ was within the range of estimates for the subtropical North Atlantic (Landrum et al., 2011; Mompean et al., 2013; Montoya et al., 2002), Baltic Sea (Sommer et al., 2006; Wannicke et al., 2013), and pelagic waters off the New Caledonian shelf (Hunt et al., 2015). The gradual decline of zooplankton $\delta^{15} \mathrm{~N}$ values did not match the large increase in $\mathrm{N}_{2}$ fixation rates measured during VAHINE, evident in the declining percent DDN ingested day ${ }^{-1}$, particularly during $\mathrm{P} 2$. This may be explained in part by a lag between ingestion and assimilation of DDN (Rolff, 2000). However, another factor may have been the rapid export of DDN from the water column, limiting zooplankton ingestion of new DDN production (Bonnet et al., 2016a).

The combination of qPCR and ${ }^{15} \mathrm{~N}_{2}$ labelled grazing experiments provided insights into the potential role of direct grazing on diazotrophs as a pathway for DDN into the zooplankton food web. A caveat of our sampling for the qPCR study was a prolonged period $(\sim 6 \mathrm{~h})$ between sample collection and $-80^{\circ} \mathrm{C}$ freezing. Although the samples were stored damp and in an ice container prior to freezing, it is likely that at least some gut evacuation would have occurred because the samples were not anesthetized immediately upon collection (Gannon and Gannon, 1975). Moreover, the qPCR assays were highly specific for their respective targets and as such, if the animals consumed other targets (i.e. other diazotrophs or nondiazotrophs) these would not have been detected or quantified. Finally, DNA extraction is not $100 \%$ and underestimation of the targets was therefore also possible.

However, the results from the qPCR assays do provide qualitative insights into zooplankton ingestion of the targeted diazotrophs, and prey selection. All four of the qPCR targeted diazotrophs (Trichodesmium spp., het-1, het-2, UCYNC) were found in zooplankton guts. Overall, the most frequently detected targets were het- 1 and UCYN-C. Het-1 was most frequently detected in the zooplankton during P1 and the beginning of $\mathrm{P} 2$, when this group dominated the diazotroph community (Turk-Kubo et al., 2015). Similarly, UCYN-C was most frequently detected in the zooplankton during P2, consistent with the UCYN-C bloom observed during that period. Although target occurrence in the zooplankton largely reflected the prevalence of the diazotroph in the water column, high detection was also recorded outside of periods of peak diazotroph occurrence. For example, the highest abundance (277 nifH copies/copepod) for the Trichodesmium spp. target measured by qPCR was on day 16 in M2, despite low water column abundance of this diazotroph at that time; and het- 2 was typically bd with the exception of day 2 when 277 nifH copies/copepod were measured, again despite having low water column abundance at that time. This indicates that the generally low abundance of Trichodesmium spp. and het-2 may have been due in part to top down control through zooplankton grazing.

The ${ }^{15} \mathrm{~N}_{2}$ labelled grazing experiments supported direct zooplankton grazing on UCYN-C, and assimilation of ingested UCYN-C-derived N. Conversely, weak if any assimilation of DDN was measured in the experiments where the diazotroph community was dominated by het- 1 and Trichodesmium spp. This was a surprising finding given that het-1, and to a lesser extent Trichodesmium spp., was detected in high abundance in copepod guts. A contributing factor to the apparent low direct het-1 and Trichodesmium spp. DDN uptake may have been a lower atomic enrichment of these diazotrophs. Indeed, the atomic enrichment of UCYN-C was more than double that of Trichodesmium spp. in this experiment. Unfortunately, the atomic enrichment of het- 1 was not measured and thus could not be assessed as a factor in the low-to-zero atomic enrichment of the copepods in E1. Another contributing factor may have been variable encounter rates of zooplankton with diazotroph prey. The total diazotroph abundance levels at the start of E2 and E4 were double $\left(\sim 3.6 \times 10^{5}\right.$ and $4.5 \times 10^{5}$ nifH copies $\mathrm{L}^{-1}$, respectively) those of $\mathrm{E} 1\left(1.5 \times 10^{5}\right.$ nifH copies $\mathrm{L}^{-1}$; Turk-Kubo et al., 2015). Lower zooplankton encounter rates with het-1 may therefore have been a factor in the low rate of DDN uptake during E1. Overall, therefore, questions remain as to the efficiency of direct assimilation of het- 1 and Trichodesmium spp. DDN by zooplankton. However, low-tozero atomic enrichment of zooplankton in E1, despite a $72 \mathrm{~h}$ incubation, and previous observations that the filamentous Trichodesmium spp. may not be easily digested by zooplankton (O'Neil and Roman, 1992), do suggest that indirect path- 
ways of Trichodesmium spp. and het-1 DDN (through, e.g. microzooplankton or nondiazotrophic phytoplankton utilizing the dissolved DDN pool) to the zooplankton are likely to be important.

As far as we are aware, this study provides the first evidence of direct zooplankton grazing on UCYN-C. The average size of UCYN-C cells during VAHINE $(5.7 \mu \mathrm{m})$ was on the lower end of the spectrum effectively grazed by copepods, the dominant zooplankton during the experiment (Fortier et al., 1994). However, an observation during the VAHINE experiment was that the majority of the UCYN$\mathrm{C}$ existed as aggregates (100-500 $\mu \mathrm{m}$ in size), likely making them more accessible to these grazers (Bonnet et al., 2016a). During VAHINE it was estimated that $\sim 16 \%$ of total fixed $\mathrm{N}_{2}$ during the UCYN-C bloom period was released to the dissolved pool, of which $\sim 20 \%$ was transferred to nondiazotrophic phytoplankton within $24 \mathrm{~h}$ (Bonnet et al., 2016a). Therefore, although direct grazing on UCYN-C was demonstrated in this study, it is likely that secondary pathways were also important in UCYN-C DDN transfer to zooplankton. Notably, the largest decline in zooplankton $\delta^{15} \mathrm{~N}$ values during VAHINE was observed during the UCYN-C bloom in M1, further supporting an important contribution of UCYN$\mathrm{C}$-derived $\mathrm{N}$ to zooplankton biomass in the New Caledonian lagoon.

\section{Conclusions}

The natural $\mathrm{N}$ isotope abundance of the zooplankton sampled during the VAHINE experiment gave clear evidence for the importance of DDN to the zooplankton food web in the oligotrophic south-west New Caledonian lagoon. The mean DDN contribution to zooplankton biomass at the start of the experiment was $\sim 28 \%$ indicating that the natural summer peak in diazotroph production in this region was already contributing significantly to the lagoon plankton food web. Stimulation of $\mathrm{N}_{2}$ fixation rates in the VAHINE mesocosms corresponded with a weak enhancement of DDN contribution to zooplankton biomass. This DDN contribution peaked at $\sim 73 \%$ in $\mathrm{M} 1$ which is on the high end of estimates from other regions.

qPCR analysis, targeting four of the common diazotroph groups present during VAHINE (Trichodesmium spp., het1, het-2, UCYN-C), demonstrated that all were ingested by copepod grazers. The most frequently detected targets were het-1 and UCYN-C, and their abundance in the zooplankton corresponded with their periods of peak abundance in the mesocosms (P1 and $\mathrm{P} 2$, respectively). ${ }^{15} \mathrm{~N}_{2}$ labelled grazing experiments provided evidence for direct ingestion and assimilation of UCYN-C-derived $\mathrm{N}$ by the zooplankton, but not for het-1 and Trichodesmium spp. We suggest that secondary pathways of Trichodesmium spp. and het-1 DDN to the zooplankton are likely to be important.
As far as we are aware, this is the first reported instance of direct UCYN-C grazing by zooplankton. Aggregation may make this small diazotroph more accessible to zooplankton grazers, however, in the absence of aggregation, a high contribution to the dissolved pool, makes UCYN-C-derived $\mathrm{N}$ accessible to the zooplankton via secondary pathways. Through a combination of these $\mathrm{N}$ transfer pathways it is evident that UCYN-C-derived $\mathrm{N}$ contributes significantly to the zooplankton food web in the New Caledonia lagoon.

Acknowledgements. Funding for this research was provided by the Agence Nationale de la Recherche (ANR starting grant VAHINE ANR-13-JS06-0002), the INSU-LEFE-CYBER program, GOPS, and IRD. The authors thank the captain and crew of the R/V Alis. We acknowledge the SEOH diver service from IRD Noumea as well as the technical service of the IRD Research Institute of Noumea for their helpful technical support, together with C. Guieu, J.-M. Grisoni, and F. Louis from the Observatoire Oceanologique de Villefranche-sur-mer (OOV) for the mesocosm design and the useful advice. During this project, Brian P. V. Hunt was funded from the European Union's Seventh Framework Programme for research, technological development and demonstration under grant agreement no. 302010 - project ISOZOO. The qPCR work was sponsored by NSF (BIO OCE 0929015) and Knut and Alice Wallenberg grants to Rachel A. Foster. Brandon J. Conroy was supported by NSF project DGE-0840804 and NSF project OCE-0934036 awarded to D. Steinberg.

Edited by: E. Marañón

\section{References}

Aberle, N., Hansen, T., Boettger-Schnack, R., Burmeister, A., Post, A., and Sommer, U.: Differential routing of "new" nitrogen toward higher trophic levels within the marine food web of the Gulf of Aqaba, Northern Red Sea, Mar. Biol., 157, 157-169, 2010.

Altabet, M. A.: Variations in nitrogen isotopic composition between sinking and suspended particles: implications for nitrogen cycling and particle transformation in the open ocean, Deep-Sea Res., 35, 535-554, 1988.

Berman-Frank, I., Bidle, K. D., Haramaty, L., and Falkowski, P. G.: The demise of the marine cyanobacterium, Trichodesmium spp., via an autocatalyzed cell death pathway, Limnol. Oceanogr., 49, 997-1005, 2004.

Berthelot, H., Bonnet, S., Camps, M., Grosso, O., and Moutin, T.: Assessment of the dinitrogen released as ammonium and dissolved organic nitrogen by unicellular and filamentous marine diazotrophic cyanobacteria grown in culture, Front. Mar. Sci., 2, 80, doi:10.3389/fmars.2015.00080, 2015a.

Berthelot, H., Moutin, T., L'Helguen, S., Leblanc, K., Hélias, S., Grosso, O., Leblond, N., Charrière, B., and Bonnet, S.: Dinitrogen fixation and dissolved organic nitrogen fueled primary production and particulate export during the VAHINE mesocosm experiment (New Caledonia lagoon), Biogeosciences, 12, 40994112, doi:10.5194/bg-12-4099-2015, 2015b. 
Biegala, I. C. and Raimbault, P.: High abundance of diazotrophic picocyanobacteria $(<3 \mu \mathrm{m})$ in a Southwest Pacific coral lagoon, Aquat. Microb. Ecol., 51, 45-53, 2008.

Boling, W., Sinclair, G., and Wawrik, B.: Identification of calanoid copepod prey species via molecular detection of carbon fixation genes, Mar. Biol., 159, 1165-1171, 2012.

Bonnet, S., Berthelot, H., Turk-Kubo, K., Cornet-Barthaux, V., Fawcett, S., Berman-Frank, I., Barani, A., Grégori, G., Dekaezemacker, J., Benavides, M., and Capone, D. G.: Diazotroph derived nitrogen supports diatom growth in the South West Pacific: a quantitative study using nanoSIMS, Limnol. Oceanogr., in revision, 2016a.

Bonnet, S., Berthelot, H., Turk-Kubo, K., Fawcett, S., Rahav, E., l'Helguen, S., and Berman-Frank, I.: Dynamics of $\mathrm{N}_{2}$ fixation and fate of diazotroph-derived nitrogen in a Low Nutrient Low Chlorophyll ecosystem: results from the VAHINE mesocosm experiment (New Caledonia), Biogeosciences, 13, 2653-2673, doi:10.5194/bg-13-2653-2016, 2016 b.

Bonnet, S., Moutin, T., Rodier, M., Grisoni, J.-M., Louis, F., Folcher, E., Bourgeois, B., Boré, J.-M., and Renaud, A.: Introduction to the project VAHINE: VAriability of vertical and tropHIc transfer of diazotroph derived $\mathrm{N}$ in the south wEst Pacific, Biogeosciences, 13, 2803-2814, doi:10.5194/bg-13-28032016, 2016c.

Capone, D. G., Ferrier, M. D., and Carpenter, E. J.: Amino acid cycling in colonies of the planktonic marine cyanobacterium Trichodesmium thiebautii, Appl. Environ. Microbiol., 60, 39893995, 1994.

Capone, D. G., Zehr, J. P., Paerl, H. W., Bergman, B., and Carpenter, E. J.: Trichodesmium, a Globally Significant Marine Cyanobacterium, Science, 276, 1221-1229, 1997.

Capone, D. G., Burns, J. A., Montoya, J. P., Subramaniam, A., Mahaffey, C., Gunderson, T., Michaels, A. F., and Carpenter, E. J.: Nitrogen fixation by Trichodesmium spp.: An important source of new nitrogen to the tropical and subtropical North Atlantic Ocean, Global Biogeochem. Cy., 19, doi:10.1029/2004GB002331, 2005.

Carpenter, E. J., Joseph, P. M., James, B., Margaret, R. M., Ajit, S., and Douglas, G. C.: Extensive bloom of a $\mathrm{N}_{2}$-fixing diatom/cyanobacterial association in the tropical Atlantic Ocean, Mar. Ecol.-Prog. Ser., 185, 273-283, 1999.

Church, M. J., Short, C. M., Jenkins, B. D., Karl, D. M., and Zehr, J. P.: Temporal Patterns of Nitrogenase Gene (nifH) Expression in the Oligotrophic North Pacific Ocean, Appl. Environ. Microbiol., 71, 5362-5370, 2005.

Clarke, K. R. and Warwick, R. M.: A further biodiversity index applicable to species lists: Variation in taxonomic distinctness, Mar. Ecol.-Prog. Ser., 216, 265-278, 2001.

Cole, M. L., Valiela, I., Kroeger, K. D., Tomasky, G. L., Cebrian, J., Wigand, C., McKinney, R. A., Grady, S. P., and Carvalho da Silva, M. H.: Assessment of a $\delta \mathrm{N}$ isotopic method to indicate anthropogenic eutrophication in aquatic ecosystems, J. Environ. Qual., 33, 124-132, 2004

Dore, J. E., Brum, J. R., Tupas, L. M., and Karl, D. M.: Seasonal and interannual variability in sources of nitrogen supporting export in the oligotrophic subtropical North Pacific Ocean, Limnol. Oceanogr., 47, 1595-1607, 2002.
Field, J. G., Clarke, K. R., and Warwick, R. M.: A practical strategy for analysing multispecies distribution patterns, Mar. Ecol.-Prog. Ser., 8, 37-52, 1982.

Fortier, L., Le Fevre, J., and Legendre, L.: Export of biogenic carbon to fish and to the deep ocean: the role of large planktonic microphages, J. Plankton Res., 16, 809-839, 1994.

Foster, R. A. and O'Mullan, G. D.: Nitrogen-Fixing and Nitrifying Symbioses in the Marine Environment, in: Nitrogen in the Marine Environment, edited by: Capone, D. G., Brook, D. A., Mulholland, M. R., and Carpenter, E. J., Elsevier, Science, 2008.

Foster, R. A., Subramaniam, A., Mahaffey, C., Carpenter, E. J., Capone, D. G., and Zehr, J. P.: Influence of the Amazon River plume on distributions of free-living and symbiotic cyanobacteria in the western tropical north Atlantic Ocean, Limnol. Oceanogr., 52, 517-532, 2007.

Gannon, J. E. and Gannon, S. A.: Observations on the Narcotization of Crustacean Zooplankton, Crustaceana, 28, 220-224, 1975.

Gifford, D. J. and Caron, D. A.: Sampling, preservation, enumeration and biomass of marine protozooplankton, in: ICES Zooplankton Methodology Manual, edited by: Wiebe, P., Lenz, J., Skjoldal, H. R., and Huntley, M., Academic Press, London, 2000.

Glibert, P. M. and Bronk, D. A.: Release of Dissolved Organic Nitrogen by Marine Diazotrophic Cyanobacteria, Trichodesmium spp, Appl. Environ. Microbiol., 60, 3996-4000, 1994.

Gruber, N., Friedlingstein, P., Field, C. B., Valentini, R., Heimann, M., Richey, J. E., Romero-Lankao, P., Schulze, D., and Chen, C.: The vulnerability of the carbon cycle in the 21 st century: An assessment of carbon-climate-human interactions, in: The Global Carbon Cycle: Integrating Humans, Climate, and the Natural World, edited by: Field, C. B. and Raupach, M. R., Island Press, Washington, D. C., 2004.

Guo, C. and Tester, P. A.: Toxic effect of the bloom-forming Trichodesmium sp. (cyanophyta) to the copepod Acartia tonsa, Nat. Toxins, 2, 222-227, 1994.

Hannides, C. C. S., Popp, B. N., Landry, M. R., and Graham, B. S.: Quantification of zooplankton trophic position in the North Pacific Subtropical Gyre using stable nitrogen isotopes, Limnol. Oceanogr., 54, 50-61, 2009.

Hewson, I., Govil, S. R., Capone, D. G., Carpenter, E. J., and Fuhrman, J. A.: Evidence of Trichodesmium viral lysis and potential significance for biogeochemical cycling in the oligotrophic ocean, Aquat. Microb. Ecol., 36, 1-8, 2004.

Hunt, B., Gurney, L., and Pakhomov, E.: Time-series analysis of hydrological and biological variability on the Prince Edward Island (Southern Ocean) shelf, Polar Biol., 31, 893-904, 2008.

Hunt, B. P. V., Allain, V., Menkes, C., Lorrain, A., Graham, B., Rodier, M., Pagano, M., and Carlotti, F.: A coupled stable isotope-size spectrum approach to understanding pelagic foodweb dynamics: A case study from the southwest sub-tropical Pacific, Deep-Sea Res. Pt. II, 113, 208-224, 2015.

Hutchins, D. A., Fu, F. X., Zhang, Y., Warner, M. E., Feng, Y., Portune, K., Bernhardt, P. W., and Mulholland, M. R.: $\mathrm{CO}_{2}$ control of Trichodesmium $\mathrm{N}_{2}$ fixation, photosynthesis, growth rates, and elemental ratios: Implications for past, present, and future ocean biogeochemistry, Limnol. Oceanogr., 52, 1293-1304, 2007.

Hutchins, D. A., Fu, F. X., and Mulholland, M. R.: Nutrient cycles and marine microbes in a $\mathrm{CO}_{2}$-enriched ocean, Oceanography, 22, 128-145, 2009. 
Karl, D., Letelier, R., Tupas, L., Dore, J., Christian, J., and Hebel, D.: The role of nitrogen fixation in biogeochemical cycling in the subtropical North Pacific Ocean, Nature, 388, 533-538, doi:10.1038/41474, 1997.

Knapp, A. N., Fawcett, S. E., Martínez-Garcia, A., Leblond, N., Moutin, T., and Bonnet, S.: Nitrogen isotopic evidence for a shift from nitrate- to diazotroph-fueled export production in VAHINE mesocosm experiments, Biogeosciences Discuss., under review, 12, 19901-19939, doi:10.5194/bgd-12-19901-2015, 2015.

Koski, M., Schmidt, K., Engström-Öst, J., Viitasalo, M., Jónasdóttir, S., Repka, S., and Sivonen, K.: Calanoid copepods feed and produce eggs in the presence of toxic cyanobacteria Nodularia spumigena, Limnol. Oceanogr., 47, 878-885, 2002.

Landrum, J. P., Altabet, M. A., and Montoya, J. P.: Basin-scale distributions of stable nitrogen isotopes in the subtropical North Atlantic Ocean: Contribution of diazotroph nitrogen to particulate organic matter and mesozooplankton, Deep-Sea Res. Pt. I, 58, 615-625, 2011.

Le Borgne, R.: Biological Production: Benthos and Plankton, in: Ecology of Tropical Oceans, edited by: Longhurst, A. R. and Pauly, D., Academic Press, San Diego, 1987.

Le Borgne, R., Rodier, M., Le Bouteiller, A., and Kulbicki, M.: Plankton biomass and production in an open atoll lagoon: Uvea, New Caledonia, J. Exp. Mar. Biol. Ecol., 212, 187-210, 1997.

Le Borgne, R., Douillet, P., Fichez, R., and Torréton, J.-P.: Hydrography and plankton temporal variabilities at different time scales in the southwest lagoon of New Caledonia: A review, Mar. Pollut. Bull., 61, 297-308, 2010.

Leblanc, K., Cornet, V., Caffin, M., Rodier, M., Desnues, A., Berthelot, H., Turk-Kubo, K., and Heliou, J.: Phytoplankton community structure in the VAHINE MESOCOSM experiment, Biogeosciences Discuss., doi:10.5194/bg-2015-605, in review, 2016.

Levitan, O., Rosenberg, G., Setlik, I., Setlikova, E., Grigel, J., Klepetar, J., Prasil, O., and Berman-Frank, I.: Elevated $\mathrm{CO}_{2}$ enhances nitrogen fixation and growth in the marine cyanobacterium Trichodesmium, Glob. Change Biol., 13, 531-538, 2007.

Loick-Wilde, N., Dutz, J., Miltner, A., Gehre, M., Montoya, J. P., and Voss, M.: Incorporation of nitrogen from $\mathrm{N}_{2}$ fixation into amino acids of zooplankton, Limnol. Oceanogr., 57, 199-210 2012.

Luo, Y.-W., Doney, S. C., Anderson, L. A., Benavides, M., BermanFrank, I., Bode, A., Bonnet, S., Boström, K. H., Böttjer, D., Capone, D. G., Carpenter, E. J., Chen, Y. L., Church, M. J., Dore, J. E., Falcón, L. I., Fernández, A., Foster, R. A., Furuya, K., Gómez, F., Gundersen, K., Hynes, A. M., Karl, D. M., Kitajima, S., Langlois, R. J., LaRoche, J., Letelier, R. M., Marañón, E., McGillicuddy Jr., D. J., Moisander, P. H., Moore, C. M., Mouriño-Carballido, B., Mulholland, M. R., Needoba, J. A., Orcutt, K. M., Poulton, A. J., Rahav, E., Raimbault, P., Rees, A. P., Riemann, L., Shiozaki, T., Subramaniam, A., Tyrrell, T., TurkKubo, K. A., Varela, M., Villareal, T. A., Webb, E. A., White, A. E., Wu, J., and Zehr, J. P.: Database of diazotrophs in global ocean: abundance, biomass and nitrogen fixation rates, Earth Syst. Sci. Data, 4, 47-73, doi:10.5194/essd-4-47-2012, 2012.

McCutchan, J. H., Lewis, W. M., Kendall, C., and McGrath, C. C.: Variation in trophic shift for stable isotope ratios of carbon, nitrogen, and sulfur, Oikos, 102, 378-390, 2003.

Moisander, P. H., Beinart, R. A., Hewson, I., White, A. E., Johnson, K. S., Carlson, C. A., Montoya, J. P., and Zehr, J. P.: Unicellular
Cyanobacterial Distributions Broaden the Oceanic $\mathrm{N}^{2}$ Fixation Domain, Science, 327, 1512-1514, 2010.

Mompean, C., Bode, A., Benitez-Barrios, V. M., Dominguez-Yanes, J. F., Escanez, J., and Fraile-Nuez, E.: Spatial patterns of plankton biomass and stable isotopes reflect the influence of the nitrogen-fixer Trichodesmium along the subtropical North Atlantic, J. Plankton Res., 35, 513-525, 2013.

Montoya, J. P., Carpenter, E. J., and Capone, D. G.: Nitrogen fixation and nitrogen isotope abundances in zooplankton of the oligotrophic North Atlantic, Limnol. Oceanogr., 47, 1617-1628, 2002.

Mulholland, M. R. and Capone, D. G.: Stoichiometry of nitrogen and carbon utilization in cultured populations of Trichodesmium IMS101: Implications for growth, Limnol. Oceanogr., 46, 436443, 2001.

Mulholland, M. R. and Bronk, D. A.: Dinitrogen fixation and release of ammonium and dissolved organic nitrogen by Trichodesmium IMS101, Aquat. Microb. Ecol., 37, 85-94, 2004.

O’Neil, J. M.: Grazer interactions with nitrogen-fixing marine cyanobacteria: Adaptation for N-acquisition?, Bulletin of the Institute of Oceanography, 19, 293-317, 1999.

O’Neil, J. M. and Roman, M. R.: Grazers and associated organisms of Trichodesmium, in: Marine Pelagic Cyanobacteria: Trichodesmium and other Diazotrophs, edited by: Carpenter, E. J., Capone, D. G., and Rueter, J. G., Kluwer Academic Press, Dordrecht, 1992.

O'Neil, J. M. and Roman, M. R.: Ingestion of the cyanobacterium Trichodesmium spp. by pelagic harpacticoid copepods Macrosetella, Miracia and Oculosetella, Hydrobiologia, 292293, 235-240, 1994.

O’Neil, J. M., Metzler, P. M., and Glibert, P. M.: Ingestion of $15 \mathrm{~N}_{2}$ labelled Trichodesmium spp. and ammonium regeneration by the harpacticoid copepod Macrosetella gracilis, Mar. Biol., 125, 8996, 1996.

Ouillon, S., Douillet, P., Lefebvre, J. P., Le Gendre, R., Jouon, A., Bonneton, P., Fernandez, J. M., Chevillon, C., Magand, O., Lefèvre, J., Le Hir, P., Laganier, R., Dumas, F., Marchesiello, P., Bel Madani, A., Andréfouët, S., Panché, J. Y., and Fichez, R.: Circulation and suspended sediment transport in a coral reef lagoon: The south-west lagoon of New Caledonia, Mar. Pollut. Bull., 61, 269-296, 2010.

Rodier, M. and Le Borgne, R.: Population and trophic dynamics of Trichodesmium thiebautii in the SE lagoon of New Caledonia, Comparison with T. erythraeum in the SW lagoon, Mar. Pollut. Bull., 61, 349-359, 2010.

Rolff, C.: Seasonal variation in $\delta^{13} \mathrm{C}$ and $\delta^{15} \mathrm{~N}$ of size-fractionated plankton at a coastal station in the northern Baltic proper, Mar. Ecol.-Prog. Ser., 203, 47-65, 2000.

Sellner, K. G., Olson, M. M., and Olli, K.: Copepod interactions with toxic and non-toxic cyanobacteria from the Gulf of Finland, Phycologia, 35, 177-182, 1996.

Sheridan, C. C. and Landry, M. R.: A 9-year increasing trend in mesozooplankton biomass at the Hawaii Ocean Time-series Station ALOHA, ICES J. Mar. Sci., 61, 457, 2004.

Sigman, D. M., Altabet, M. A., Michener, R., McCorkle, D. C., Fry, B., and Holmes, R. M.: Natural abundance-level measurement of the nitrogen isotopic composition of oceanic nitrate: an adaptation of the ammonia diffusion method, Mar. Chem., 57, 227-242, 1997. 
Sigman, D. M., Altabet, M. A., McCorkle, D. C., Francois, R., and Fischer, G.: The $\delta 15 \mathrm{~N}$ of nitrate in the southern ocean: Consumption of nitrate in surface waters, Global Biogeochem. Cy., 13, 1149-1166, 1999.

Sommer, S., Hansen, T., and Sommer, U.: Transfer of diazotrophic nitrogen to mesozooplankton in Kiel Fjord, Western Baltic Sea: a mesocosm study, Mar. Ecol.-Prog. Ser., 324, 105-112, 2006.

Torréton, J.-P., Rochelle-Newall, E., Pringault, O., Jacquet, S., Faure, V., and Briand, E.: Variability of primary and bacterial production in a coral reef lagoon (New Caledonia), Mar. Pollut. Bull., 61, 335-348, 2010.

Turk-Kubo, K. A., Frank, I. E., Hogan, M. E., Desnues, A., Bonnet, S., and Zehr, J. P.: Diazotroph community succession during the VAHINE mesocosm experiment (New Caledonia lagoon), Biogeosciences, 12, 7435-7452, doi:10.5194/bg-12-7435-2015, 2015.
Vanderklift, M. A. and Ponsard, S.: Sources of variation in consumer-diet $\delta^{15} \mathrm{~N}$ enrichment: a meta-analysis, Oecologia, V136, 169-182, 2003.

Wannicke, N., Korth, F., Liskow, I., and Voss, M.: Incorporation of diazotrophic fixed $\mathrm{N}_{2}$ by mesozooplankton - Case studies in the southern Baltic Sea, J. Mar. Syst., 117-118, 1-13, 2013.

Zehr, J. P.: Nitrogen fixation by marine cyanobacteria, Trends Microbiol., 19, 162-173, 2011. 